\title{
Influence of Supply Chain Management to Performance Through Strategic Cooperative Operations in the Field of Food Production Cooperative in West Bandung regency.
}

\author{
Yun Yun ${ }^{1}$, Ina Primiana ${ }^{2}$, Umi Kaltum ${ }^{3}$ \\ \{yunyun@lecture.unjani.ac.id ${ }^{1}$, ina.primiana@fe.unpad.ac.id ${ }^{2}$, umi.kaltum@gmail.com ${ }^{3}$ \} \\ ${ }^{1}$ Management Departement, Faculty of Economic and Business, Universitas Jenderal Achmad Yani, \\ Terusan Jenderal Sudirman Street, Cimahi, West Java, Indonesia \\ ${ }^{2,3}$ Management Departement, Faculty of Economic and Business, Universitas Padjdjajaran' Dipatiukur \\ Street, Bandung, West Java, Indonesia
}

\begin{abstract}
Cooperative Performance in Indonesia still low Because cooperative contribution to GDP is still low. Whereas the number of Cooperatives most Widely in the world. Cooperatives at West Java $30 \%$ as not active Cooperatives. The low performance of Cooperatives Because of The limitation of capacity to manage the product. Other than that, the problem at Cooperatives is a limitation of own technology. Damage to products from suppliers to consumers reach. This researcher aims to impact of supply chain management to Cooperatives performance through strategic cooperative operations in food production in West Bandung District. This objective is the cooperative food research productions. The objective of this research's cooperative food production in West Bandung District. This research uses partial least square method structure equation modeling (PLS-SEM). The result of this research shows the strong impact and significant supply chain management to cooperative performance through strategic operation, where have the impact of supply chain management to Cooperatives performance through strategic operations.
\end{abstract}

Keywords: Cooperative Performance, Supply Chain Management, Strategic Cooperative

\section{Introduction}

Food security becomes a strategic matter for the Indonesian government, in order to improve the welfare of society. Food products become essential to be met all the family of Indonesia so as to improve the welfare and certainty in living life. Indonesia has a population of more than 200 million people, in need of food supply with a large capacity.

Other problems caused also by the food product supply chain is relatively long. the Long supply chain that causes costs to be inefficient so that the growth performance of the production of food products to be low. Food products that require large capacity in the distribution supply chain need the support of a good to be efficient. Inefficiencies saw from the level of loss of products up to twenty percent of start production until the product reaches the consumer.

Cooperative as a forum for people to improve the economic security can be used to increase food production. Through cooperative farmers can be managed and given the knowledge of the development of agricultural technology. So the cooperatives have the potential to improve food security community. 
Performance of cooperatives in West Java is still unfavorable, West Java province has a cooperative inactive percentage reaches $30 \%$ of the total existing cooperatives. The high cooperatives that are inactive due to poor performance in the managerial cooperative and the ability to manage business sectors are still low. Cooperatives are faced with free competition is quite difficult to compete mainly because they lack the ability of administrators in managing the cooperative organizations they manage. Thus, often the inability to make the existing cooperative becomes inactive.

Supply chain network through the appropriate operating strategy can improve the performance of the cooperative, because through good distribution will improve the organization's marketing performance while through a network of suppliers will have an impact on the efficiency of the operations of the cooperative. Cooperative performance as measured by performance marketing and financial performance is strongly influenced by the implementation of supply chain management. Smoothness in implementing supply chain management is highly correlated to the performance of the cooperative. In addition, the operating strategy as a bridge between supply chain management with cooperative performance.

There is a relationship between the application of supply chain environment and market base, the operational base and the accounting base to company performance. The results of these studies that the company's performance can be explained by the application of supply chain environment as well as the operational base [1].

Supply chain management is needed to integrate the information and material flows smoothly through the supply chain as an effective competitive weapon [2]. Agricultural products that require information and smooth material flow necessary to run supply chain an effective so that products offered can be accepted by the customer on time.

Performance of cooperatives should be increased because of the decrease in the community who depend on livestock and agriculture businesses. Community in West Bandung regency is turning to other businesses outside the business of production agriculture.

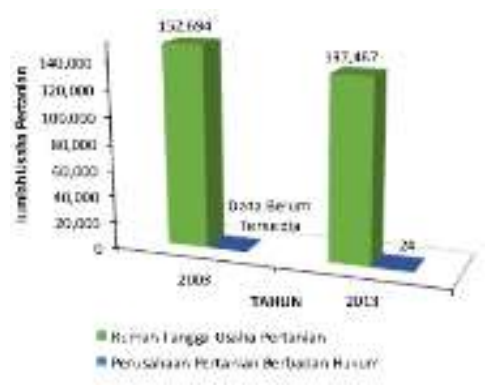

Source: [3]

Fig. 1. Growth of Household Agriculture

Households agricultural businesses in West Bandung district decreased by 15137 households of 152269 households in 2003 to 137467 households in 2013, which means a decrease of $9.91 \%$ per ten bps year, 2013. the data directing that a decline in people who work in agriculture, it is disrupting agricultural production in West Bandung regency.

Cooperative production of the food sector in the area of West Bandung in his efforts have been engaged in agriculture, livestock and plantations and fisheries. Based on the data 
recorded, the number of cooperatives engaged in agriculture as much as 133 cooperatives, three cooperative farms, plantations, and fisheries cooperative 118 cooperatives so that the total amounted to 157 cooperatives[4] .

The low performance of cooperatives is the one caused by the low use of appropriate technology that is utilized so that farmers manage livestock traditionally make quality cow's milk produced becomes less good, other than that, most of the farmers are small farmers who own cattle less than three tails make production capacity very small cow makes the burden of fixed costs in the production process to be great. Another issue of dairy cows are susceptible to damage makes the distribution of the product should be fast [5].

In addition, for many agricultural cooperatives, there are problems between the mismatch between supply and demand of agricultural products. Often the supply of agricultural products flooding the market, so the price is low so that the lack of information and product over supply makes the farmers harmed by low prices. In addition, the presence of which less fertilizer, especially during the growing season, causing farmers to plant late [6] [5].

Based on the above background, the researchers are interested in making a research on "the effect of supply chain management through the operation of the performance of the cooperative strategy areas of food production in West Bandung regency".

Based on the research background. The formulation of the problem in this research is: How supply chain management, operations strategy and performance of cooperatives in the areas of food production cooperatives in West Bandung regency. How to influence supply chain management the performance of food cooperatives in West Bandung regency. How to influence supply chain management the strategy of operations in food cooperatives in West Bandung regency. How to influence the performance of the operating strategy of the food cooperative in West Bandung regency. How to Influence the Supply Chain management on the performance of the cooperative through cooperative operation strategy in the field of food production in West Bandung regency.

\section{Literature Review}

\subsection{Supply Chain Management}

Supply Chain has many definitions that describe the process of a product from the receipt of raw materials, production processes in the company and product delivery on customer orders. supply chain associated with the integration carried out between suppliers, manufacturing, and distributors who do in order to fulfill customer orders. as submitted by [7] supply chain as a whole interaction between suppliers, manufacturers, distributors, and consumers. Chopra and [8]Supply chain is the whole part including the direct or indirect to fulfill customer orders. Supply chain not only manufacturing and suppliers but there are supporting other that customer orders can be fulfilled from transport, warehousing, retailers and customers themselves. As stated by [8] that the supply chain is not only manufacturing and suppliers, but also includes the transportation, storage, retailers and consumers themselves.

The implementation of SCM as a series of activities that run the organization to carry out effective management of the supply chain. [9] Identify the supply chain into a strategic supplier partnership, customer relationship, and information sharing as key to the implementation of the supply chain.

\subsection{Operations Strategy}


The strategy has developed since about 1960, according to Skinner, in [10] as a series of planning strategies and policies that aim to get an edge over the competition. Companies must implement appropriate strategies to gain a competitive advantage from the price, quality, and responsiveness to customers.

Leong et al. in [11] operating strategies differentiated according to content and process. Content presenting strategic issues that must be resolved by the management. The methods and procedures used to reflect the decision-making process of the development of operating strategies. So the operation strategy is a method of decision-making related to the development of the operating strategy to be able to complete a wide range of issues associated with the operating strategy.

operating strategy instead of focusing on the individual, but rather the overall business transformation intact [12]. In the short term, identified three generic strategies that focus on the cost of operation, resulting in high product quality, and strive to apply the latest technologies and processes [13] [14].

Operating strategies according to Swamidas in [15] to demonstrating the new approach that refers to the ability of manufacturing (manufacturing competency) which is distinguished from the planning approach top-down conventional.

The strategy focuses on the importance of producing quality products and services that can satisfy the specifications and needs of consumers. Companies must pay attention to the quality improvement so as to reduce production costs.

Operations strategy is not focused on the individual and more to the overall transformation process on its core business [12]. Operations strategy should reflect the four perspectives: top-down, bottom-up, market requirements and operations resources [12].

Operating strategy intended to gain a competitive edge over the competition in terms of product quality, price, flexibility, and delivery. In order to achieve this goal then made a decision that the operating strategies that goal can be achieved by either. Decisions in the operating strategy including [12] Capacity Strategy, Supply Network Including purchasing and logistics strategy, Process technology strategy, Development and organization.

\subsection{Cooperative performance}

As a cooperative performance, the achievements of a company in one period is always synonymous with performance, whether it is the employee's performance or the performance of the company. Performance shows the results obtained based on the capabilities that have been sacrificed during the period. So that the results so far obtained achievement an individual/company showed their performance in one period [16] [17].

Performance Management can be seen from the final results of work of an institution both government agencies, the private sector, and civil society organizations. Argued that the dimensions of management performance measurement targets include reliability (dependability), flexibility. So that issues related to cooperative management performance can't be separated from matters relating to the benefits to be obtained by members as owners and customers, among others the promotion of members, successful members(success member) and the successful development of cooperatives : Reliability, Flexibility. Promotions member, Successful development of cooperatives [16].

\section{Research Methods}

This research using descriptive and associative method [18]. This reseach measuring three variabel that the independent variables are latent supply chain management $(\mathrm{X})$ and the 
latent dependent variable is the operating strategy (Y1) and cooperative performance (Y2). Elements in the path analysis PLS-SEM in figure 3.1, namely inner models and outer models. Inner models described the relationship arrows between independent latent variables $(\mathrm{X})$ and the dependent variable (Y1 and Y2). Outer model of the relationship shown by arrows between latent variables either dependent or independent and indicators. The outer model consists of two measurements of reflective and normative models. Population in this research is food production cooperative in West Bandung area. This research used 90 responden. Criteria of the responden is chairman of food production cooperative. Method to choice the responden used simple random sampling. Measuring of reflective contained in latent variables $\mathrm{Y} 1$, and $\mathrm{X}$. The arrows are shown on the latent variables to the indicators. While variable $\mathrm{Y} 2$ is illustrated the formative measurement of arrows of indicators to variables. Error occurs when a latent independent variables affect the dependent variable latency. In PLS-SEM to measure using the program SMARTPLS 3 [18].

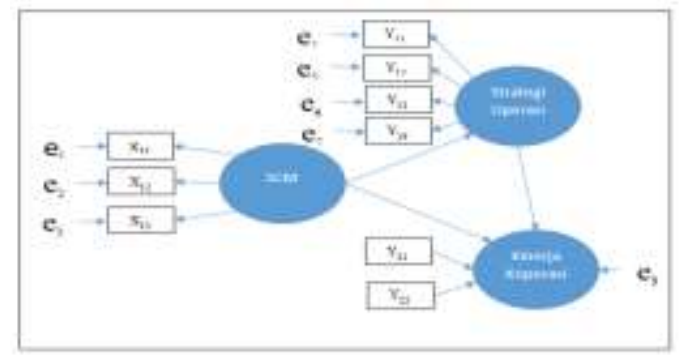

Fig. 2. Model PLS-SEM

The analysis in PLS-SEM explains the relationship between the latent variables in the inner models and the relationship between the latent variables and indicators in the outer models. After estimating the model PLS-SEM, the next step is to evaluate how well the model we built based on the data samples are taken. Evaluation of the structural model is based on an evaluation using a nonparametric procedures bootstrapping and blindfolding. There are two models of PLS-SEM measurement is an evaluation of the measurement model (outer model) and structural models(inner model).

\subsection{Evaluation Outer Model Reflective}

Outer evaluation models aimed at evaluating the indicator variables. Measurement model latent variables in PLS-SEM there are two models of a reflective and formative model. The Reflective model evaluation consists of Indicator reliability. Discriminant validity. Internal consistency. Composite reliability, Convergent validity.

\section{Results and Discussion}

The main objective of this study is to determine the effect of supply chain management on the performance of the cooperative through cooperative operation strategy in the field of food production in West Bandung regency. These problems the author makes a model with the help SmartPLS.

The next step after that is starting the process model is created PLS algorithm, 
bootstrapping and blindfolding. PLS algorithm and bootstrapping are calculated to obtain the value loading factor of all the indicators of research, the path coefficient value, the value of $\mathrm{R}^{2}$, the value of $\mathrm{T}$ Statistic and other necessary coefficients to determine the convergent validity and discriminant validity of the research model. The results of PLS algorithm and process bootstrapping may be seen in Figure 4.4 and 4.5 below.

\section{PLS algorithms}

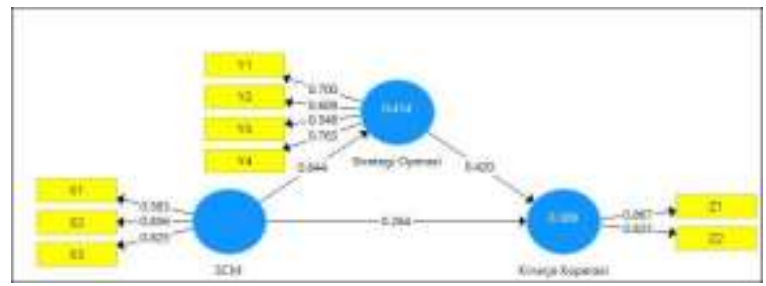

Fig. 3. Effect of Supply Chain Management on the Performance of Cooperative through Operations Strategy of Cooperative Production Division of Food in West Bandung regency process PLS Alogaritm

Source: Questionnaire, reprocessed 2016

\subsection{Influence of Supply Chain Management to Performance Through Strategic Cooperative Operations In Food Sector Production Cooperative in West Bandung regency}

Here calculated path of influence the supply chain management on the performance of the cooperative through cooperative operation strategy in the field of food production in West Bandung regency.

Table 1. Effect of Supply Chain Management on the Performance of Cooperative through Operation

\begin{tabular}{|c|c|c|c|c|}
\hline Variable & $\begin{array}{l}\text { Coefficient } \\
\text { Line }\end{array}$ & Direct Impact & $\begin{array}{l}\text { Indirect Influence } \\
\text { (via)Operations } \\
\text { Strategy }\end{array}$ & Total Effect of \\
\hline $\begin{array}{c}\text { Supply Chain } \\
\text { Management }\end{array}$ & 0.264 & $6.7 \%$ & $7.3 \%$ & $14 \%$ \\
\hline Operating Strategy & 0.420 & $17 \%$ & - & $17 \%$ \\
\hline Effect Entire & \multicolumn{3}{|c|}{} \\
\hline
\end{tabular}

\section{Source : Questionnaire, reprocessed 2016}

from the table above 4:23, operations strategy provides the greatest influence on the performance of cooperatives in the areas of food production cooperatives in West Bandung regency. The table can explain that $6.7 \%$ of the cooperative's performance can be explained by variable supply chain management. Variable cooperative performance can be explained by the variable operating strategy by $17 \%$ and the rest is explained by other variables. Furthermore, whether these variables significantly affect the performance of Cooperatives.

\section{Conclusions}

Based on the results of research discussing the influence of supply chain management on 
the performance of cooperatives through the operation strategy on food production cooperatives in West Bandung regency can be summed up as follows

1. Supply chain management has a positive effect on cooperative performance. So to be able to optimize its performance, both management performance and business performance. the cooperative must optimize its supply chain. An effective supply chain can have a positive effect on cooperative performance.

2. Supply chain management has a positive influence on operating strategy. It shows to be able to run its cooperative operating strategy must be able to maintain its supply chain, partnerships with suppliers important to maintain supply stability and coordination with customers to ensure demand for the product. So there must be a division of relevant information to keep operations strategy so that the company's operations to be efficient.

3. Cooperative performance is also influenced by the operation strategy. So the company must be able to optimize its operation strategy so that cooperative performance can increase. Efficiency in operational matters is important to maintain business continuity and improve cooperative performance.

4. Supply chain management has a positive effect on cooperative performance through operating strategy. Maintaining customer relationships is supported by good partnerships with suppliers. The existence of certainty of raw materials from suppliers will provide a more definite operating strategy. The existence of certain of the operations will have a positive impact on the performance of the cooperative.

\section{Reference}

[1] S. L. Golicic and C. D. Smith, "A meta-analysis of environmentally sustainable supply chain management practices and firm performance," J. Supply Chain Manag., vol. 49, no. 2, pp. 78-95, 2013.

[2] G. M. Mbuthia and G. Rotich, "Effects Of Supply Chain Management Practices On Competitive Advantage In Retail Chain Stores In Kenya, A Case Study Of Nakumatt Holding Limited," Eur. J. Bus. Manag., vol. 2, no. 1, 2014.

[3] "No Title." [Online]. Available: bps.go.id.

[4] "No Title."www.

[5] S. Luthra, K. Govindan, D. Kannan, S. K. Mangla, and C. P. Garg, "An integrated framework for sustainable supplier selection and evaluation in supply chains," $J$. Clean. Prod., vol. 140, pp. 1686-1698, 2017.

[6] B. Huo, Y. Qi, Z. Wang, and X. Zhao, "The impact of supply chain integration on firm performance," Supply Chain Manag. An Int. J., vol. 19, no. 4, pp. 369-384, 2014.

[7] Heizer and B. Render, Operation Management: Sustainability and Supply Chain Management. England: Pearson Education, 2018.

[8] S. Chopra and P. Meindl, Supply Chain Management Strategy, Planning, and Operation. Pearson, 2013.

[9] S. Li, B. Ragu-Nathan, T. S. Ragu-Nathan, and S. Subba Rao, "The impact of supply chain management practices on competitive advantage and organizational performance," Omega, vol. 34, no. 2, pp. 107-124, 2006.

[10] M. Schlickel, The Effect of Strategy Style on Strategy Cascading. Springer, 2013.

[11] S. Khalili Shavarini, H. Salimian, J. Nazemi, and M. Alborzi, "Operations strategy and business strategy alignment model (case of Iranian industries)," Int. J. Oper. Prod. Manag., vol. 33, no. 9, pp. 1108-1130, 2013. 
[12] N. Slack, A. Brandon-Jones, and R. Johnston, Operations Management. 2013.

[13] C. E. Armstrong, "Competence or flexibility? Survival and growth implications of competitive strategy preferences among small US businesses," J. Strateg. Manag., vol. 6, no. 4, pp. 377-398, 2013.

[14] R. G. Schroeder, M. J. Rungtusanatham, and S. Goldstein, Operations Management in the Supply Chain: Decisions and Cases. 2012.

[15] H.-L. Chan, B. Shen, and Y. Cai, "Quick response strategy with cleaner technology in a supply chain: coordination and win-win situation analysis," Int. J. Prod. Res., vol. 7543, no. January, pp. 1-12, 2017.

[16] A. Nelly, "Business performance measurement: Unifying theory and integrating practiceNo Title," Cambridge Univ. Press, 2007.

[17] K. C. Tan, "Supply Chain Management: Practice and Performance in New Zealand," no. July, 1999.

[18] A. Widarjono, Analisis Multivariat Terapan dengan program SPSS, AMOS, SMARTPLS, Edisi 2. Yogyakarta: UPP STIM YKPN., 2015. 